\title{
Sovereignty, belligerency and the new normal in cyberspace
}

Pål Wrange 1

University of Stockholm

Submitted version of chapter published in Linda Bishai (ed.), Law, Security and the State of Perpetual Emergency, Palgrave, 2020, 67-105.

\section{SUMMARY}

This essay will discuss how intrusive (hacking) cyber espionage in peacetime is legally justified, in particular by some US defense sources. In their reading, "cyberspace" has become a virtual "space" of exception from the usual peacetime rules of respect for sovereignty. Given the ubiquitous and interlinked nature of "cyberspace", exceptions previously applicable only in war or in other hostile relations, have now de facto become the rule, and states have sought ways to rationalise and justify that, without openly flouting the established categories of war, peace and sovereignty. In the US, this has occurred through a very limited conception of sovereignty (sovereignty as a non-binding principle). This leaves much of "cyberspace" in a legal no-mansland, or more adequately, a free-for-all-land, in which states can search and manipulate data on computers in foreign states without much legal consequence. This very limited conception of territorial sovereignty is related to the metaphorical spatialalisation of the Internet as a new "domain", a "cyberspace", rather than as a network of hardware located in interlinked but still separate national jurisdictions.

\section{Introduction}

Our world has for long been governed by mutually exclusive dichotomies like peace and war, sovereign police powers and belligerent war powers, state actors and nonstate actors, ordinary powers and exceptions. These distinctions have never been undisputed, but now the fundaments are being challenged. For sure, there have always been grey zones, or pockets of exceptions and belligerency in territories of peaceful sovereignty. In contests between states, like the Cold War, this was manageable, because life could go on as usual in the vast expanses of everyday life between those pockets. By contrast, states now may find themselves in hostile (though not yet 
belligerent) relations with both other states and non-state groups (like terrorist groups), and these relations are not territorially or even functionally limited. We live in a world where threats appear to be omnipresent and omnidirectional. Nowhere are the classical categories as blurred as in "cyberspace", where the same cables and protocols are being used by everyone - NSA (the National Security Agency), FSB (the Russian security service), ISIS (the Islamic State in Iraq and Syria), Facebook, the local electricity company and health provider and you and me. As explained by two prominent lawyers in the field:

The technological structure and global interconnectedness of cyberspace offers both state and nonstate actors a medium through which to operate against a broad array of targets, free from the physical constraints of geography and territorial boundaries. At an increasing rate, states are not just utilizing, but also aggressively exploiting, cyberspace .... Likewise, nonstate actors routinely use cyberspace to conduct harmful activities .... For example, ISIS uses the internet to command and control its operations, spread its toxic propaganda, recruit new members, and incite violence globally. (Corn \& Taylor, 2017, p. 207)

What does this mean for law and its exceptions? The prevailing view is that the classical dichotomies still apply and continue to provide the compass for lawyers to navigate. However, those who manage security in our world, and in particular in "cyberspace", are not completely comfortable in those confines.

This chapter will discuss how intrusive (hacking) cyber espionage in peacetime is legally justified, in particular by US and to some extent UK governmental sources. ${ }^{2}$ It will focus on the phenomenon of intrusive cyber espionage, but much of the general argument could pertain also to other offensive cyber operations, like cyber sabotage and other forms of cyberattacks. A cyber operation (or cyberspace operation) is defined widely by the US Department of Defense, "[ $t]$ he employment of cyberspace capabilities where the primary purpose is to achieve objectives in or through cyberspace" (USJCS, 2018, p. I-1). These can be of different form. Cyber attacks are "[a]ctions taken in cyberspace that create denial effects (i.e., degradation, disruption, or destruction)" which are noticable in cyberspace or a physical domain (USJCS, 2018, p. GL-4). Cyber exploitation, which is a slightly broader term than cyber espionage, is defined as "[a]ctions taken in cyberspace to gain intelligence, maneuver, collect information, or perform other enabling actions required to prepare for future military operations" (ibid). In this context, an enabling action may consist of the installing of a so-called backdoor, which makes it possible for someone to monitor activities in a system; hence, it is an operation that facilitates intelligence gathering. For the purpose of this article, I define intrusive cyber espionage as information gathering as a result of unauthorized remote access to data, that is, the entry into a computer system without permission. ${ }^{3}$ Intrusions

Sovereignty, belligerency and the new normal in cyberspace Wrange.docx 
can be done for various purposes, including to prepare future military operations. These types of operations are sometimes referred to as HACKINT.

This essay will not cover SIGINT, which consists of eavesdropping on messages sent through satellites, the ether or in cables. ${ }^{4}$ The legal and moral issues are partly, but only partly, similar, and will therefore not fit the format of this chapter. Further, the chapter will not deal with the use of force (jus ad bellum) or the law of armed conflict or international humanitarian law (jus in bello) in "cyberspace", but only with what lies beneath these thresholds. Perhaps most importantly, the chapter will not focus particularly on intelligence gathering that targets private parties, which is what has made many people concerned after the Snowden revelations. In some but not all respects, private and public targets for cyber operations are treated differently and that difference is a very interesting issue, which calls for a separate critical analysis. Likewise, this text will not discuss the use of data which individuals or others have provided voluntarily (though sometimes mindlessly), as in the Cambridge Analytica scandal. Unless indicated otherwise, whenever cyber espionage as HACKINT is discussed in this essay, it refers to acts that may be conducted against both state and non-state actors, including private persons.

My claim is that "cyberspace" has become a virtual "space" of exception in which the usual rules do not apply or, to be more precise, in which the rule has been so diminished that exceptions seem almost unnecessary (at least as far as US policy is concerned). State cyber operations are undertaken in a professional culture of espionage $^{5}$ and covert operations, which have always functioned in an implicit state of exception. However, given the ubiquitous and interlinked nature of "cyberspace", this exception has now de facto become the rule, and states (and their legal officers) have therefore sought ways to rationalise and justify that, without openly flouting the established categories of war, peace and sovereignty.

Legally and politically, this has not occurred through an explicit or even implicit designation of "cyberspace" as a space of exception, but indirectly, through a very limited conception of sovereignty, which leaves much of "cyberspace" in a legal nomans-land, or more adequately, a free-for-all-land. This conceptualisation is not accepted by the overwhelming majority of international lawyers that are active in the field, but it is the governing conception of the US and UK cyber forces ${ }^{6}$. I argue that this conception is related to the metaphorical spatialalisation of the Internet as a cyber"space", rather than simply as networked hardware located in different national jurisdictions. $^{7}$

First, I will explain how international law and classical categories like sovereignty are generally held to be applicable to cyber operations, which requires that I set out some general international law principles of international law relating to sovereignty. I will

Sovereignty, belligerency and the new normal in cyberspace Wrange.docx 
then outline two different types of legal analyses pertaining to cyber operations, and how they have fitted into some current practices in "cyberspace". ${ }^{8}$ The last part will provide an effort to explain these analyses in more theoretical terms, and what they implicate. Since the purpose of this chapter is not to make a case for one or the other view of what the law says, I will refrain from invoking legal sources in the body text, and just state each view under discussion and its consequences, as I find them.

One important caveat: As I will explain later, the evocative word "cyberspace" ${ }^{9}$ invites us to think about this phenomenon (or these phenomena) in particular ways, which in turn suggests certain ways of thinking about how to regulate it (or them). "Cyberspace" can be defined differently, but for US military planners, it consists of three interrelated layers: physical network (the hardware), logical network (the code), and cyber-persona (digital representations of actors) (USJCS, 2018, p. I-2). As will be clear towards to end of this chapter (though only by implication) I find it problematic to link these three layers into one thing, in particular for the purpose of the application of international law. Nevertheless, I will defer to established practice and use the term, but within quotation marks. ${ }^{10}$

\section{Legal and conceptual background}

\section{Sovereign and belligerent rights}

It is useful to think about these matters under the dichotomy "sovereign and belligerent rights" (or powers), which is a feature of US legal thinking about armed conflicts, including in the US Law of War Manual from 2015 (USDOD, 2015, p. 1025). ${ }^{11}$ Under international law, a sovereign government (the sovereign) has both rights and obligations towards its subjects (individuals and corporate actors) as well to others who have subjected themselves to the sovereign, for instance by entering its territory (cf Neff, 2005, p. 251,272). The sovereign right to make and enforce laws against private subjects is inextricably linked to the duty to respect the human rights of these subjects. ${ }^{12}$ The external corollary of this sovereign right is the obligation to respect the sovereignty of other states, that is, the principle of sovereign equality. This obligation, generally agreed among international lawyers, entails that state A cannot exercise authority in the territory of state B, meaning that it cannot enforce its laws or decisions in B. ${ }^{13}$ Hence, boundaries between states are also boundaries that determine the right to exercise authority as enforcement.

A sovereign state can, of course, also be a belligerent, a party to an armed conflict $\left(w^{14}{ }^{14}\right)$. In contrast to the sovereign's peaceful relations with its subjects and other sovereigns, the relation between belligerents is one of enmity and equality. Belligerent rights, as regulated by the law of war (or international humanitarian law [IHL] or jus in Sovereignty, belligerency and the new normal in cyberspace Wrange.docx 
bello), ${ }^{15}$ apply between states as well as between states and enemy private parties, ${ }^{16}$ and they only apply during war. In the exercise of belligerent rights, a state's forces may kill enemy combatants and destroy enemy property (subject to restrictions) but it may not attack civilians. In modern law -- domestic and international -- the exercise of sovereign rights in peace is the rule, while the application of belligerent rights in wartime (armed conflict) is the exception, but an exception that is also governed by law, as just explained. As will be developed below, some lawyers think that espionage for national security purposes may be subject to another exception, seemingly as a quasi-belligerent right (or jus extra bellum; Adams, 2014). Yet other lawyers think that sovereignty is so restricted that no exception needs to be invoked at all, as will also be discussed.

\section{International law in "cyberspace"}

How does this apply in "cyberspace"? Communication between computers is routed in international webs mostly operated by private networks, which are not controlled by any one government. ${ }^{17}$ Some observers have suggested that the Internet is beyond the sovereignty of governments, ${ }^{18}$ or even a new dimension, not subject to the same regulation as other domains of human activities (see Schmitt, 2013). ${ }^{19}$

Nevertheless, the Internet and other computer networks have physical locations, under the territorial jurisdiction of one or more states, and the actors have nationality, regardless of whether they are individuals or corporations (see Kanuck, 2009, p. 1573). Governments are increasingly taking control over their national "cyberspaces" and have consequently assumed jurisdiction over computer networks in a progressively assertive way. As a further corollary, states now generally agree in very general terms that international law as it currently exists applies to computer networks (von Heinegg, 2012, p. 9-10). This was confirmed in a report from a broadly representative group of governmental experts in a UN report from 2013:

19. International law, and in particular the Charter of the United Nations, is applicable $\cdots$

20. State sovereignty and international norms and principles that flow from sovereignty apply to State conduct of ICT-related activities, and to their jurisdiction over ICT infrastructure within their territory (GGE 2013). ${ }^{20}$

Still, the legal situation is far from clear. With the exception of the 2001 Budapest Convention against Cybercrime, and possibly some provisions in the International Telecommunication Convention (ITU, 2010, Chapter VI), there is no international convention on the topic. ${ }^{21}$ The quoted UN report is the closest thing we have to an authoritative intergovernmental opinion. There are few instances of opinio juris (state legal opinion), ${ }^{22}$ little confirmed state practice, and no judgments or reports from

Sovereignty, belligerency and the new normal in cyberspace Wrange.docx 
international adjudicative or monitoring bodies. ${ }^{23}$ States have been unable to agree on more than very general concepts, and while this lack of clarity creates frustration for many governmental interests, it can also be an opportunity for those who want to exploit it.

However, the scholarly discussion has increased during the last few years, in particular after the publication in 2017 of the Tallinn Manual 2.0 on the International Law Applicable to Cyber Operations, a commentary written by scholars independent of, but facilitated by, the NATO Cooperative Cyber Defence Centre of Excellence in Tallinn. ${ }^{24}$ The publication of Tallinn 2.0 prompted an intense discussion on sovereignty in "cyberspace". This discussion provides a not only convenient but also pertinent focal point for the ensuing analysis. Most of the legal writers that will be cited here took part in some way or the other in the process leading to the Tallinn Manual 2.0.

\section{International law and cyber operations}

States may conduct many types of cyber operations that affect information in hardware in other states, such as search of information to prevent or investigate crimes and terrorism, interdiction of cyber-attacks, planting of false information, or manipulation or interruption of the functioning of critical infrastructure like electricity grids or election administration. Some of these measures may damage hardware and software, but even more of them will constitute unauthorized intrusions in computers, illegal under domestic law.

Writers generally hold that cyber attacks (or computer network attacks) that cause considerable "kinetic" damage may constitute illegal use of force under Article 2(4) of the UN Charter (Tallinn, 2017, p. 46 et seq), while there is controversy regarding whether "mere" destruction or manipulation of data might reach that level. ${ }^{25}$ Such attacks are very rare; the anonymous Stuxnet virus against Iran in 2010-2012 constitutes the most debated example of what might amount to the use of force. ${ }^{26}$ A cyber attack that constitutes force may be an initiation of an armed conflict, but if it takes place within the scope of an already ongoing conflict, the question of the UN Charter will be immaterial; ${ }^{27}$ instead the main question will be whether it complies with IHL (and perhaps also human rights). ${ }^{28}$ In cyber law discourse, writers often sometimes refer to the armed conflict threshold; for the purposes of this chapter, that threshold will be assumed to be the same as the threshold for use of force. ${ }^{29}$

Until a few years ago, the scholarly discussion stopped here. If an act did not cross the threshold to use of force, it appeared to be more or less unproblematic. However, many such acts may constitute illegal intervention or violations of sovereignty. Writers now generally agree that the principle of non-intervention applies in "cyberspace" (O'Connell, 2012, p 6; Buchan, 2012, p. 223; Gill 2013, p. 217 et seq). Nevertheless,

Sovereignty, belligerency and the new normal in cyberspace Wrange.docx 
intervention, in the sense defined by for instance the UN Friendly Relations Declaration of 1970, is not the focus here. It involves "measures to coerce another State in order to obtain from it the subordination of the exercise of its sovereign rights and to secure from it advantages of any kind," which only covers actions that explicitly target the will of the opponent and which is also a fairly high threshold. ${ }^{30}$

Instead, the emphasis will be on cyber operations below the thresholds of use of force and intervention with a focus on cyber exploitation including cyber espionage. Such operations may -- or may not -- constitute violations of state sovereignty. As will be discussed below, the dominant view is that international law applies to such acts. Before proceeding, it is necessary to briefly address the extraterritorial aspect. Cyber operations, including cyber espionage, are generally carried out from abroad. ${ }^{31}$ Although this cross-border feature has been seen to be relevant by experts (some more than others), ${ }^{32}$ no one has suggested that remote operations are never illegal.

\section{Espionage and international law}

Espionage is but one form of intelligence. Intelligence is about collecting information and analysing it so that it becomes useful for a client, for instance a policy or a military organization. Much information for intelligence purposes is gathered from open sources, including on the internet (OSINT, open source intelligence). Among other forms of data collection one finds those involving human sources (HUMINT), signals intelligence (SIGINT; see above) and a host of other types of measures.

It is often unclear what commentators mean by "espionage". There is no authoritative international definition, but the better view is that espionage, or secret intelligence, is about obtaining information "covertly--that is, without the consent of the State that controls the information" (Chesterman, 2009). Hence, the core of espionage is the nonconsensual obtaining of information ("exfiltration"). Obviously, in order to achieve that, a spy often needs to go through some other accessory (or associated) measures ${ }^{33}$ that may violate laws -- domestic or international -- such as illegal entry into a country, bribery or burglary. In "cyberspace", that typically consists of unauthorized access of private and public data, so called HACKINT. ${ }^{34}$ As will be further discussed below, when making a legal assessment of espionage, it is important to distinguish between the core activity (exfiltration of information) and the accessory activities.

Espionage is, of course, permitted in war on the territories of the belligerents. As for espionage in other states or in peacetime, the situation is not so clear. There are international regulations which can be held to restrict both espionage and/or the accessory acts, such as those that protect the human right to privacy of individuals as well as the confidentiality and inviolability of diplomatic premises, archives and

Sovereignty, belligerency and the new normal in cyberspace Wrange.docx 
correspondence. Further, there are broader principles, like the principle of sovereignty, that many writers will hold to be directly relevant to the core act of espionage and/or to the accessory acts, as will be discussed. However, although states usually prohibit espionage under their domestic laws, there is no specific international regulation of peacetime espionage per se. ${ }^{35}$

There are essentially three schools of international legal thought in this respect. The first one is that espionage is illegal as such, as most famously argued by Quincy Wright (Wright, 1962, p. 11; see Forcese, 2011, p. 202; Chesterman, 2006, p. 1074-75). In Wright's view, espionage is illegal under international law by virtue of being illegal under the domestic law of the target country, thus violating territorial sovereignty (Wright, 1962, p. 12). The second, and much more common view is that the core act (the exfiltration) is not regulated, and therefore not prohibited. Hence, the legality depends on the legality of other acts associated with the exfiltration. This is the view adopted in the Tallinn Manual, where the participants had, however, different views on the legality of the accessory acts, as will be discussed. According to the third view, which has become slightly more prevalent lately, states have accepted espionage as legal, as an exception to the general rule of sovereignty as well as to other potentially applicable rules. Whether that legality also covers all accessory acts under this view is not always clear. Nevertheless, what virtually all writers in the field have in common is the prediction that the law regarding cyber espionage may change - possibly in a more permissive direction -- as state practice and opinio juris develop (Watts \& Richard, 2018, p. 777; Corn \& Taylor, 2017, p. 211; Schmitt \& Vihul, 2017a, p. 217; Phil Spector, 2017, p. 223).

I will discuss each of these views, but in a different matrix, namely the dichotomy of sovereignty-as-a-rule and sovereignty-as-a-principle. ${ }^{36}$ As will be shown, all three opinions on espionage can fit under the sovereignty-as-a-rule moniker, albeit with quite different conceptions of this rule, while the sovereignty-as-a-principle view -- which has been expounded only by a handful of writers, but important ones at that -- results in the conclusion that espionage is legal (unless it reaches the level of intervention or use of force).

Hence there are three views about whether cyber espionage as HACKINT (below the thresholds of intervention and force) is legal and two views on sovereignty, and the relation between the views on these two issues can be summarised in this table:

\section{HACKINT below the thresholds}

Sovereigntists

Some think never legal

Most think sometimes legal

Some think always legal Always legal

Sovereignty, belligerency and the new normal in cyberspace Wrange.docx 
Since the first two views (never legal, sometimes legal) actually project on a continuum of opinions, they will be discussed under a common heading. And that brings us over to the core of this essay.

\section{The legality or not of intrusive cyber espionage}

As implied above, the interconnectedness of information technology enables operations of a type and scale not available previously, not least to nonstate actors. Further, hostile cyber operations nearly always come not directly from an easily identifiable hostile base but via globally dispersed computers. These computers are often co-opted by the attacker without the knowledge of the owners, and the governments in charge of the territories where they are located may lack both knowledge of the attacks and the capacity to act against them (Corn \& Jensen, 2018b; Corn \& Taylor, 2017, p. 211). The attacker may be governmental or nongovernmental, her identity will often be concealed, in the attack many other subjects and territories will be implicated, and the attack will usually not be a part of an ongoing belligerent relation (an armed conflict).

In order to meet these threats, states will conduct preemptive or counter attacks and collect intelligence, both to prepare against cyber attacks and for general purposes. States therefore need to address hostile acts from both other states and nonstate actors, from the territory of the adversary as well as from other places, and they need to do it both in war and in peace. In order to address the alleged mismatch between the nature of contemporary cyber threats and the reigning dichotomies in international law and politics, a number of legal options are possible in theory. However, not all have actually been suggested. No one has explicitly proposed that the distinction between war and peace be abandoned in "cyberspace". That would legalize any cyber operation, but states that have offensive capabilities are usually also very vulnerable to attacks. ${ }^{37}$ Further, no one has suggested that sovereignty should be completely abandoned. Even the non-sovereigntist view, which will be referenced below, holds that certain crucial corollaries of sovereignty, like the prohibition of the use of force, apply in "cyberspace". In fact, any of those proposals would be very difficult to make for an international lawyer, whose job is based on the premises of sovereignty and the war/peace distinction. Instead, the response has been to try to move around or between these fundamental categories. Belligerent rights in existing armed conflicts could be extended territorially to include acts in territories beyond the theatre of war (as in the war on terror). One could also argue that exceptional, "quasi-belligerent" rights could cover relations which are not yet fully belligerent but nevertheless hostile. Sovereign rights could also in some respects be extended to territory which is not under the sovereignty of the acting state, thus allowing some actions against hostile but not belligerent Sovereignty, belligerency and the new normal in cyberspace Wrange.docx 
adversaries, not least non-state actors, or against belligerent enemies beyond the theatre of war, without the burden of invoking belligerent or "quasi-belligerent" rights. Further, one could argue for a high threshold for what is a prohibited cyber operation, arguing that only a very severe intrusion on hardware in other states constitutes a violation of international law. It also needs to be pointed out that to invoke belligerent rights also has a price; while it significantly increases the legal room of manoeuvre, belligerency is reciprocal and offers the same rights to the opponent.

\section{"Sovereigntists": Sovereignty as a rule}

As indicated above, such responses can be categorised within the dichotomy sovereignty-as-a-rule/sovereignty-as-a-principle. I will call the first group of writers "sovereigntists", although not all of them would be comfortable with that term. ${ }^{38}$ They all proceed from the view that sovereignty is a rule (or a binding principle ${ }^{39}$ ) with direct effects, including the right of a sovereign to have its territory and its sovereign prerogatives respected by other states. This group of writers have slightly different ways of explaining this rule and, more importantly, they also have quite different views about what it means to have territory and sovereign prerogatives respected in "cyberspace"; in fact, some of them actually come close to the (much smaller) nonsovereigntist camp as far as the concrete regulation is concerned. Nevertheless, lawyers within this group still accept the fundamental premise of "base-line sovereignty" (Watts \& Richard, 2018).

\section{Territorial sovereignty}

The sovereigntist argument proceeds from the established international law conception of territorial sovereignty..$^{40}$ Perhaps the most iconic explanation of what that means is Judge Huber's dictum in the Island of Palmas case of 1928. "Sovereignty in the relations between states signifies independence. Independence in regard to a portion of the globe is the right to exercise therein, to the exclusion of any other State, the functions of a State" (Island of Palmas, 1928, p. 838). This view is developed further in the seminal Lotus judgment by the Permanent Court of International Justice in the preceding year: "Now the first and foremost restriction imposed by international law upon a State is that --failing the existence of a permissive rule to the contrary -- it may not exercise its power in any form in the territory of another State." (Lotus, 1927, p 18.)

However, to say that sovereignty does indeed apply in "cyberspace" is only the beginning of any discussion. First of all, while the sovereigntists hold that territorial sovereignty prima facie prohibits or restricts cyber operations on foreign territory (Tallinn, 2017, p. 17), they do allow such acts under some, generaly applicable circumstances (Tallinn, 2017, p. 18 and rules 20 and 26). ${ }^{41}$ A state may take

Sovereignty, belligerency and the new normal in cyberspace Wrange.docx 
countermeasures against wrongful cyber operations from another state in order to induce the target state to comply with its obligations. States may also invoke necessity, if that is necessary to an essential interest against a grave and imminent peril. Further, in some cases intrusive cyber operations - especially cyber espionage -- can be rationalised by the more obtrusive arguments of estoppel or tu quoque. ${ }^{42}$

Secondly, even though these expcetions are relevant and grosso modo accepted in international law, our main interest is whether the general rule - territorial sovereignty -- allows cyber espionage. As already implied, to say that sovereignty applies also in "cyberspace" is not necessarily to say that cyber espionage is prohibited, and as mentioned, the views on that rule can be divided into three groups: Those who believe that espionage is generally prohibited, those who believe that it may be legal or illegal depending on the circumstances (not least the degree of infringement produced by how it is carried out, the accessory act) and those who find that it is generally legal (as a carveout/exception).

\section{Espionage and the legality of the accessory act}

As mentioned, the first view is that espionage is always illegal, since it violates the domestic law of the other state, while the second view is that the legality hinges on whether the accessory acts, associated with the exfiltration of information, are in accordance with international law or not. I will discuss these two views under the same heading, since they have in common that they do not believe in a special carvout for espionage (the third view), and since they actually place themselves on a continuum, where some people who pay attention to the accessory act actually come very close to the first, very strict view. The Tallinn IGE represented the full spectrum of these views, and the intricacy of the discussions reflected the complexity of the issues. The IGE assessed the matter in two different respects: (1) "the degree of infringement upon the target State's territorial integrity" and (2) "whether there has been an interference with or usurpation of inherently governmental functions" (Schmitt and Vihul, 2017a, p. 215; Tallinn Manual, 2018, p. 20.) The first aspect, infringement of territorial integrity, was in its turn analysed on three levels: (1) infringement upon territorial integrity falling below the threshold of loss of functionality, (2) loss of functionality and (3) physical damage.

As for the first level, the strictest opinion is that any non-consensual operation by a government agent on foreign territory, cyber or not, violates international law. Under this view, any "nonconsensual interference with the integrity of cyber infrastructure on the territory of other States" violates sovereignty (Watts \& Richard, 2018, p. 771; see also Buchan, 2015). In one take of this view, the rule of thumb is that acts that domestic law prohibits for a private person (i.e. a person without public authority) are not allowed for a foreign state under international law. ${ }^{43}$ For instance, acts like search of a home or

Sovereignty, belligerency and the new normal in cyberspace Wrange.docx 
of computer data are illegal for a private person (burglary or as unauthorized data access) and they are thus prohibited under international law (unless there is a permission) ${ }^{44}$ Under this view, there is no distinction between different acts depending on the purpose of the act - law enforcement, national security, economic interest or otherwise. Within the IGE, a small minority held that a violation of sovereignty may have been caused by "a cyber operation causing cyber infrastructure or programs to operate differently; altering or deleting data stored in cyber infrastructure without causing physical or functional consequences...; emplacing malware into a system; installing backdoors; and causing a temporary, but significant, loss of functionality, as in the case of a major DDoS operation" 45 (Tallinn, 2017, p. 21). This enumeration clearly covers acts associated with cyber espionage. These contributors ground their view on the object and purpose of sovereignty, namely a legal guarantee of "full control over access to and activities on their territory" (Tallinn, 2017, p. 21).

Moving to the second level, most members of the IGE took a less strict view and adopted an "effects-based approach", meaning that mere exfiltration or insertion of malicious code (malware), like a backdoor would not constitute a violation of sovereignty; more concrete harm is needed (Tallinn, 2017, p. 20-21). This view, of course, assumes the premise that no harm is caused if information is merely copied (exfiltrated), that is, that loss of confidentiality is not a harm. ${ }^{46}$ The majority of members of the IGE held that if there is loss of functionality as a consequence of an operation, that would constitute a violation of sovereignty (Tallinn, 2017, p. 20-21; Schmitt, 2017, p. 6; Watts \& Richard, 2018, p. 825). Views were, though, divided as to the degree of damage required (Tallinn, 2017, p. 20-21).

Proceeding up to the third level, some members had an even more liberal view and required physical damage for there to be a violation, for instance if malware causes the cooling elements of a computer to stop functioning, which leads to overheating and destruction of hardware (Tallinn, 2017, p. 20; Schmitt, 2017, p. 6).

To continue the account of this broad school of thoughts into the second aspect: The other - and disjunctive - set of criteria for illegality discussed by the members of the IGE was whether a state, "by means of cyber operations, interferes with or usurps functions that lie at the heart of the other's independence"(Schmitt \& Vihul, 2017a, p. 216). The Manual cites the afore quoted "Island of Palmas" award, and holds illegal "remote operations that interfere with, or usurp, inherently governmental functions, because the target State undeniably enjoys an exclusive right to perform them on its territory" (Schmitt 2017, p. 6; Tallinn 2017, p. 21-22). This means that "cyber activity [which] interferes with a State's governmental functions" violates sovereignty. The Manual holds, inter alia, elections, law enforcement and national defense as examples of activities that a foreign state may not interfere with, regardless of whether coercion has

Sovereignty, belligerency and the new normal in cyberspace Wrange.docx 
been involved or not (Tallinn, 2017, p. 22, 24). As noted by Watts \& Richard (2018, p. 826), this comes close to being an effects-based criterion and thus belong to the first aspect. The International Group of Experts further concurred that it would constitute an illegal usurpation for a foreign State to conduct inherently governmental functions exclusively reserved to the territorial State such as the exercise of law enforcement functions without consent or authority under international law (Tallinn, 2017, rule 11, p. 22). However, it is to be noted that this apparently only applied to explicit exercise of certain forms of public authority; if a state conducts a search on a foreign computer outside the framework of a criminal law investigation or other exercise of authority, that would not be covered by this set of criteria by the IGE. Hence, it does not cover typical cyber espionage.

\section{Espionage as legal (a carveout)}

The third view is, as indicated, that there is an exception for espionage. This view was represented by a small minority in the Tallinn discussions. These commentators think that while territorial sovereignty may very well apply to "cyberspace", there is a carveout which allows espionage (in spite of it being prohibited by domestic law), regardless of what one thinks of the main rule of territorial sovereignty in "cyberspace" discussed above. Hence, there is no obstacle under international law to committing espionage over the internet (Shaap, 2009, p. 140-141). While many commentators (including the IGE) hold that espionage in the restricted sense - the mere covert collection of information -- is not outlawed, the commentators in the former group still hold that the accessory acts may be illegal if they violate other rules, for instance sovereignty (Schmitt \& Vihul, 2017a, p 218). However, the "carveout lawyers" find that the act of espionage actually justifies the accessory violations (at least if they are not too serious) (Watts \& Richard, 2018, p. 826). This is so because there is a customary norm to that effect, since most or all nations engage in such activity (Deeks, 2015, p. 302; Scott, 1999, p. 226; see von Heinegg, 2012, p. 16). ${ }^{47}$

The counterargument is that "[s]tate practice, without opinio juris, cannot create a customary international law rule" (Schmitt \& Vihul, 2017b, p. 1645; see also Kozik, 2015, p. 99). In vernacular terms, this refers to the fact that customary international law is formed by both practice and opinio juris, that is, states' legal conviction that the practice is legal; while many states do engage in espionage they are seldom open about specificities and they rarely, if ever, present opinio juris which justifies this practice. Hence, opinio juris is lacking. ${ }^{48}$

At any rate, under this exception, there would be some limited, exceptional, rights for states to engage in espionage for certain purposes. Some of these writers make it explicit that the exception only applied to matters related to defence and other national security

Sovereignty, belligerency and the new normal in cyberspace Wrange.docx 
issues ${ }^{49}$ in fact turning this alleged carveout into another exception from the general law of peace -- a "quasi-belligerent" right, ${ }^{50}$ if you will, or, as one US military lawyer expressed it, a jus extra bellum (Adams, 2014, p. 404).

\section{Non-sovereigntists: sovereignty as (non-binding) principle}

Hence, the doctrine that territorial sovereignty applies in "cyberspace" can accommodate views that allow for cyber espionage under many circumstances. While the great majority of sovereigntist members of the IGE would allow at least some forms of HACKINT, those of the third view, the carveout, would even accommodate almost any type of cyber espionage. The editors of the Tallinn manual therefore thought that the conclusions of the manual could be attractive to states that have an interest in permissive regulations which allow cyber espionage and other cyber operations below the thresholds of force and intervention. Referring to the alleged need to direct cyber operations against cyber infrastructure used by terrorist groups beyond the area of hostilities, ${ }^{51}$ Schmitt and Vihul find that if such operations "neither cause physical damage to, nor a loss of functionality of, the targeted cyber infrastructure, the state conducting those operations may have a reasonable argument that such digital penetrations of foreign territory are not in breach of territorial integrity and inviolability" (Schmitt \& Vihul, 2017a, p. 216-217; Schmitt, 2017, p. 6-7). Further, there are the generally accepted exceptions for countermeasures and necessity mentioned above.

Nevertheless, some commentators have argued that the manual is too restrictive. Gary P. Corn (then head lawyer for the US Cyber Command) finds that the main rule only allows "'de minimis' effects" and he further complains that "a key limitation on the availability of [countermeasures] is that, ... unlike self-defense, countermeasures cannot be invoked as a justification for actions taken against non-state actors." Therefore, under the view guiding the Tallinn manual, "the State seeking to conduct ... cyber operations [against ISIS on foreign territory] can do so only with the consent of each State in whose territory the cyber action will occur, or based on a reasonable determination that those States are themselves in breach of an international obligation." The scope for claiming that those states are in breach of international law is limited. Corn explains: the state obligation to exercise due diligence over cyberspace to prevent harm to other states is, according to the Tallinn manual, restricted to what is "feasible". In sum, "States cannot violate another State's sovereignty to prevent trans-boundary harm, and the territorial State has no duty to monitor or prevent such action and is required to act only when the State has knowledge of the harm and can feasibly put an end to it. This is obviously an untenable gap in the law" (Corn, 2017).

Corn's analysis of the legal requirements for countermeasures and for necessity is not

Sovereignty, belligerency and the new normal in cyberspace Wrange.docx 
undisputed. ${ }^{52}$ Be that as it may, Corn and some of his colleagues have put forward the quite radical thesis that territorial sovereignty does not apply to cyber operations which take place in cyber hardware located on other states' territories. This is the view of a small minority of commentators (Watts \& Richard, 2018, p. 819, Schmitt \& Vihul, 2017b, 1641) but it is a very significant one, since they are (or were) officials of the US and the UK governments, who are important actors in "cyberspace" and also outspoken in the formation of norms; their opinions and actions matter to the development of international law. ${ }^{53}$

The thesis is based on two alternative arguments -- that territorial sovereignty is not a binding norm ("not a primary rule") and that even if it were, it does not apply in "cyberspace" (or applies only in a very restricted sense). Either of these arguments is sufficient to justify the conclusion. The first, and more radical variant is articulated by Corn. The second argument, that sovereignty at any rate does not apply in "cyberspace", has been presented by UK and US representatives in their official capacity, as will be explained below. It has also been fleshed out by former DoD lawyer Eric Talbot Jensen.

In theory there is a great difference between the view of Corn and that of for instance Jensen. Corn thinks that sovereignty is not binding as such, and that the binding rules that admittedly do regulate access to land territory and prohibit intervention, for instance, are more specific rules. Jensen, by contrast, accepts that sovereignty is a binding norm, but finds that it does not seem that states have been willing to apply it to "cyberspace". Nevertheless, they agree on the end result, that there are no rules that prohibit actions by a foreign state in another state's cyber infrastructure below the generally recognized thresholds of prohibited intervention and use of force, and they co-authored an article to that effect. ${ }^{54}$ For reasons of economy, I will only discuss the slightly less radical version, namely that regardless of whether or not sovereignty has direct legal consequences elsewhere, it does not apply in "cyberspace".

The view may appear to be shocking, ${ }^{55}$ but it needs to be pointed out that Corn's and Jensen's conception of prohibited intervention is not necessarily the most restricted one: Intervention "must be understood to encompass actions involving some level of subversion or usurpation of a victim state's protected prerogatives" (Corn \& Jensen, 2018a) and acts that "impinge on the inherently governmental functions of another state" may violate international law (Jensen, 2017, p. 742-743). This means that some of the acts that Tallinn called usurpation are covered by this wider concept of intervention; ${ }^{56}$ however, the overwhelming majority of operations that the IGE found problematic are not.

A more official DoD view was presented in some detail on January 19, 2017, the last day of President Obama's administration, when the outgoing General Counsel of the U.S.

Sovereignty, belligerency and the new normal in cyberspace Wrange.docx 
Department of Defense, Jennifer O'Connor, issued a memorandum titled "International Law Framework for Employing Cyber Capabilities in Military Operations". ${ }^{57}$ As the memo does not appear to be available on line and was subsequently labelled "internal", I will not take it to reflect an official position of the US government, but I will refer to it (from secondary sources) in order to flesh out what I believe to be the effective view in Pentagon. The memo finds that it is not an internationally wrongful act to conduct cyber operations that interfere with the integrity of cyber infrastructure on the territory of other states, to intrude into such cyber infrastructure, or to alter such systems or their data, as long as such acts do not amount to force or intervention. ${ }^{58}$

A more cautious explanation of the US position was presented in 2016 by the then legal adviser at the State Department, Brian Egan:

[R]emote cyber operations involving computers or other networked devices located on another State's territory do not constitute a per se violation of international law. In other words, there is no absolute prohibition on such operations as a matter of international law. This is perhaps most clear where such activities in another State's territory have no effects or de minimis effects (Egan, 2017, p. 174).

These words are more circumspect and do not clearly rule out that operations that have more than "de minimis effects" may violate international law, but they do not contradict Corn, Jensen, Taylor ${ }^{59}$ and $\mathrm{O}^{\prime}$ Connor. Even if Jensen, Taylor and Corn wrote in their private capacities, it seems reasonable to assume that they hold the same view while in office, and these views were confirmed and developed in the official, though retracted, memo by O'Connor. Therefore, this is the view that governs the application of international law by the US Cyber Command. The State Department might very well have a partly different opinion (Schmitt, 2017, p. 5), but it is surely Corn's view that guides US cyber operations.

Nevertheless, the most prominent expression of the non-sovereigntist doctrine, however, is the one made by the then Attorney-General of the UK, Jeremy Wright, at a speech at Chatham House in 2018.

Some have sought to argue for the existence of a cyber specific rule of a "violation of territorial sovereignty" in relation to interference in the computer networks of another state without its consent. ... I am not persuaded that we can currently extrapolate from that general principle [of sovereignty] a specific rule or additional prohibition for cyber activity beyond that of a prohibited intervention. The UK Government's position is therefore that there is no such rule as a matter of current international law. ${ }^{60}$

This presentation was warmly welcomed by Corn \& Jensen (2018a\&b). While these various statements by UK and US representatives may seem radical, it is still notable that most of these assertions about the limited reach of sovereignty (except Corn's) are

Sovereignty, belligerency and the new normal in cyberspace Wrange.docx 
qualified as being about "cyber activity", rather than being about sovereignty in general. This will be discussed further below.

\section{Conceptualising a new normal?}

As the Command Vision for the US Cyber Command (2018, p. 3) says, the "new normal" is a state where "our adversaries .. provoke and intimidate our citizens and enterprises." Cyber scholar Ron Deibert (2015, p. 11) notes that "[t]hreats are now dispersed across all of society, regardless of national borders. As a result, the focus of the state's security gaze has become omnidirectional." This is, of course, a fact that follows not only from the nature of "cyberspace", but from the nature and perception of threats in general. It is therefore no wonder that many commentators find that we are in a perpetual, indeterminate, interminable, and global state of war (Lawson \& Gehl, 2011, p. 2). The way to address this is "[t]hrough persistent action ... below the level of armed conflict" (US Cyber Command, 2018, p. 6).

For those who need to fight adversarial states like Russia or North Korea or non-state actors like ISIS in "cyberspace", the rules and institutions that were developed on the basis of classical categories like territorial sovereignty, war, and peace no longer seem to be working, so they sense a need to transgress the boundaries: to act on the territories of other states without their consent, to use exceptional measures when there is no war, and to engage directly with foreign non-state actors. Returning to the discussions on sovereign and belligerent rights in the introductions to sections 2 and 3: If one accepts the distinction between war and peace and if one accepts the concept of sovereignty, then there are essentially three ways for a state to increase its legal room of manoeuvre - to invoke and extend its belligerent rights beyond the theatre of war to third states, to invoke and extend its sovereign rights so that they also cover acts on foreign territory including acts against private, non-state parties (while preferably avoiding the corollary human rights obligations that sovereigns have vis-à-vis their subjects), and/or to find other exceptions to the law of peaceful relations between sovereigns (by using quasibelligerent measures even when there is no war). So, essentially it is about extending the geographical scope for the operations that one wants to perform (belligerent or sovereign), and/or to raise the bar for what is permitted.

\section{Exceptions are everywhere?}

Under the doctrine of "unable or unwilling" 61 - which has been invoked for belligerent acts against Al Qaeda in a number of countries - a belligerent state may justify the extension of the geographical scope of a conflict to another state, which is unable or unwilling to prevent the enemy using its territory. A recent book notes that US administration officials view the armed conflict against Al Qaeda and associated forces Sovereignty, belligerency and the new normal in cyberspace Wrange.docx 
as an armed conflict under a global law of war paradigm (Dickinson, 2018; cf US White House, 2016, p.10). Nevertheless, it is not, in fact, "war everywhere". While that conflict has been carried out in a number of countries, no administration has been willing to claim a right to pursue that war (if war is the right term) beyond a few states in the Middle East and the Horn of Africa. Hence, the US has not (yet) claimed global belligerent rights in "cyberspace". Further, there are many other adversaries of the United States with which the US does not find itself at war, and, as mentioned, there is a cost to invoking belligerency, namely that it gives the opponent the reciprocal right to use deadly and destructive force. ${ }^{62}$

However, there are other ways to argue for an extended right to use cyber operations against an adversary. One road would be to take a broad view of what is permissible self-help, including the right to take countermeasures and to invoke necessity, in particular on territories of states that are unable or unwilling to stop malicious activities. ${ }^{63}$ This would allow states to take non-belligerent action against adversaries (state or non-state actors) beyond a war theatre, without making the legally and politically difficult claim that these third states are combat zones.

Another argument, as mentioned, is to claim that there is a particular exception in international law for espionage. Those who have argued for the existence of a permissory caveat have generally limited this to espionage for national security purposes or similar, that is, for reasons broadly related to defense and thus to belligerency (Lubin, 2018, p. 222-223; Kiovaty, 2016, p. 58; Deeks, 2015, p. 305). A related thought, which appears to be common in the intelligence profession, is to think of espionage, and not least cyber espionage, as a "space between" diplomacy and military action (Lubin, 2018, p. 215; see also Segal, 2017, p. 51; Maurer, 2014). ${ }^{64}$ Hence, espionage may be a sort of activity that falls in the cracks between war and peace, or perhaps one should think of an alleged "right to spy" (Lubin, 2016. See also Sulmasy \& Yoo, 2006, p. 628 ) as a quasi-belligerent right.

Another route, which to a large extent reaches the same goal, but in other terms, is to hold that the bar for what is prohibited behaviour is high, which would give a wide room of manoeuvre. This was the path taken by many of the members of the Tallinn IGE, who left considerable leeway for remote cyber operations, including espionage and offensive operations.

At any rate, while all of these lines of argument provide some remedy for the need to extend the zone of operation and to give more leeway than the sterner sovereigntists would allow, to invoke such arguments also brings the onus on the operator to show that the territorial state is unable or unwilling, that the operation concerned really serves national security or that it does not create significant harm or usurps sovereign authority .

Sovereignty, belligerency and the new normal in cyberspace Wrange.docx 


\section{Sovereignty is nowhere (and everywhere)?}

There is another line of thinking that does not have to explain how the fight may be brought to other territories, leaves the border between war and peace intact, has no need to invoke quasi-belligerent rights, to raise the bar for intervention or to deal with the intricacies of usurpation -- for the simple reason that none of this is of much consequence, at least as concerns cyber espionage (as well as most other types of offensive cyber operations). Under this view, state A can operate freely on the territory of $B$ against non-state actor $C$ or against state $D$ or against $B$ itself, as long as it does not intervene in B's domestic affairs or exercises force. The approach chosen by Corn and others (including US and UK authorities) is to devalue sovereignty to a non-binding principle rather than a rule. Under this view, the basic premise is freedom of action, with only a few limitations, like the prohibition of intervention and the prohibition of the use of force, but no rule of territorial sovereignty.

Corn invokes the first part of the aforementioned Lotus judgment.

The principle of sovereign equality underlies the well-recognized premise in international law that '[r]estrictions on the independence of states cannot ... be presumed.' ... This premise, known as the Lotus rule, has long been understood to stand for the proposition that states are free to act on the international plane except to the extent that their actions are proscribed by treaty or customary international law. (Corn \& Taylor, 2017, p. 209)

Hence, sovereignty is invoked, not to protect the territory of the sovereign, ${ }^{65}$ but to boost the freedom to act "on the international plane." According to one of the most articulate sovereigntists in the Tallinn IGE, "the logical limit of a State's own sovereignty -- where its sovereignty ends -- is where another State's sovereignty begins" (Watts \& Richard, 2018, p. 836). For Corn, however, sovereignties do not seem to be mutually exclusive, because remote cyber operations on cyber infrastructure in another state do not take place within that state's exclusive sovereign space. Hence, a "space" outside full sovereignty has been created, a networked "space" consisting of all cyber hardware everywhere, on any territory, a "space" in which any state can exercise its sovereign rights to do anything, as long as it does not constitute intervention or use of force. It is not a "space" where sovereignty is extinguished - because the territorial sovereign still has the right to regulate within its territory - but it is diluted, or overlapping, a bit like in the territorial sea, where the littoral state has jurisdiction (albeit limited) and foreign ships have a right to traverse. ${ }^{66}$

What is to be made ofn this? Both sovereigntists and non-sovereigntists acknowledge that "cyberspace" is different: There is "the relatively nascent, hyper-dynamic and evolving nature of cyberspace, the inherent need for stealth in the execution of most cyber operations" (Corn, 2017) and further "its ubiquitous interconnectivity [and] its Sovereignty, belligerency and the new normal in cyberspace Wrange.docx 
lack of segregation between the private and public sectors" (Corn \& Taylor, 2017, p. 207), and perhaps most importantly here, its ability to "free States from many of the geographic and physical restraints that might have previously prevented access ... to information and objects on the territory of other States.." (Watts \& Richard, 2018, p. 776).

The Tallinn group tried to fit the hardware, the software and the actors (the different "layers") of "cyberspace" into established legal categories like territory and jurisdiction: "Cyber activities occur on territory and involve objects, or are conducted by persons or entities, over which States may exercise their sovereign prerogatives" (Tallinn, 2017, p. 12). The non-sovereigntists, by contrast, emphasised "the incongruity of the basic structure, design and operating protocols of the internet with traditional notions of Westphalian geography" (Corn, 2017) and the "incompatibility with traditional concepts of geography" (Corn \& Taylor, 2018, p. 207).

Since its inception, the concept of sovereignty has been tightly tied to geography. The same cannot be said of cyberspace. There is at most a tenuous connection between geography and the logical and social layers of cyberspace, i.e., the software, protocols, and data that combine to generate outputs, and the various digital identities and aliases of the human users of the internet. (Corn \& Jensen, 2018b)

Jensen (2017, p. 735) develops this in a more doctrinal fashion.

[S]overeignty is a principle that depends on the domain and the practical imperatives of states and is subject to adjustment in interstate application. Briefly contrasting how sovereignty is treated in the territorial based regimes of air, land, sea, and space illustrates the point.

He continues:

The lack of legal consistency across these domains makes the formulation of a rule that will apply to cyberspace especially difficult. It appears, based on state practice to date, that states are applying sovereignty with respect to cyberspace in a way that does not preclude cyber activities on the infrastructure and territory of another state to include actions taken by one state that do not impinge on the inherently governmental functions of another state. (Jensen, 2017 742-743; my emph.) ${ }^{67}$

The use of the word "domain" is not a stylistic choice. The US Department of Defense has designated "cyberspace" as a "fifth domain", besides land, sea, air and outer space (Deibert, 2015, p. 768; USDOD, 2015, p. 995). Corn and Taylor explain that while "[t]he principle of sovereignty is universal, ... its application to the unique particularities of the cyberspace domain remains for states to determine through state practice and/or the development of treaty rules" (Corn \& Taylor, 2017, p. 210; my emph.). This argument essentially means that "cyberspace" is a different type of "domain". 68 "Domain" has

Sovereignty, belligerency and the new normal in cyberspace Wrange.docx 
significant connotations; a new domain may be taken to suggest a tabula rasa. States quibbled for centuries about the regulation of the seas until they came to an (incomplete) agreement in the UN Convention on the Law of the Sea in 1982. When airspace (the third domain) was beginning to be used by humans in the early $20^{\text {th }}$ century, views were divided as to whether it was free or was covered by sovereignty, and the same happened when humans started to use outer space. For airspace, the generally agreed solution became to regard it as an extension of territory. For outer space, the view emerged that it essentially was free for use by anyone. While the US has consistently held that international law applies to "cyberspace", ${ }^{69}$ what these commentators suggest is that it must apply differently, by being different from land, just like the sea, airspace and outer space are different.

Both "space" and "domain" are spatial metaphors. However, while the first four "domains" of Pentagon military doctrine can be clearly demarcated on a map and have coordinates in Euclidian geometry- one can know whether one is on land, at sea, in the air or in outer space - and while they also exclude one another - one cannot be on land and in outer space at the same time -- that appears not to be the case for "cyberspace". All of the hardware of "cyberspace" as well as the software - which essentially consists of electrical charges - have locations in the other four domains, mostly on land (cf Kanuck, 2010). In fact, cyberspace has many features in common with venerably means of communication like the telegraph and the telephone, such as cables and nodes. What qualitatively does set the Internet apart is the mode of packet switching, which makes it impossible (or at least very difficult) to know how a message will be routed through the network. ${ }^{70}$ But does that mean that it is fundamentally different? Radio waves were also a new means of communicating and disseminating messages, and while states have had different views on for instance the regulation of broadcasting (Fisher, 1990), no one has suggested that radio is a separate domain. Perhaps there may be reasons to unpack and disassemble this concept and distinguish between the messages sent over the cables and the hardware in which information is stored. Perhaps "cyberspace" is not a new domain but "just" a new technology, which states (still) need to figure out how to regulate.

At any rate, before states have worked that out - which they never may - each state will continue to act under its own doctrine, with its own justifications - political, moral, legal -- for whatever it decides to do. Whether one thinks of "cyberspace" along the lines of Corn et al or along those of the Tallinn IGE, whether one starts the deliberations from "networked machines" or from "cyberspace", from "sovereignty" or from "no sovereignty", has suggestive consequences for how one thinks of the law and policy of information technology.

Sovereignty, belligerency and the new normal in cyberspace Wrange.docx 


\section{The political ontology of "cyberspace"}

As pointed out by two cyber security scholars, the ontology of cyber is political: "Cyberspaces are constantly enacted and practiced processes with consequences exceeding territorial boundaries, public-private relations, and national regulatory frames" (Christensen \& Liebetrau, 2016, p. 21) And it is also legal. Says cyberlaw scholar Nicholas Tsagourias (2015, p. 14): “Law ... constructs the ontology and function of cyberspace".

"Cyberspace" has always been the subject of ontological politics. In the 1990s, most famously perhaps in the writings of John Barlow, the term was used to escape the heavy hands of governments - for instance in the 1996 Declaration of the Independence of Cyberspace (Barlow, 1996). In the early years of the new millennium, states took control over and militarised "cyberspace", reminding us that both hardware and people were actually located in places (usually state territories) and had nationality. At the same time, states increasingly often used the term "cyberspace", perhaps because it was in vogue (US Joint Chief of Staff, 2013). In recent years, I have suggested, the term has again been taken to suggest a radical difference to the other "domains".

Political implications of terminology are, of course, not unique for "cyberspace". Nor are they in and of themselves illegitimate. The more traditional terms which we use to orient ourselves in the political world are also constructs - think of "territory" - and it cannot be otherwise. However, some constructs appear to be more malleable or openended than others. To say that territory is "just a social construct" seems pointless (if not ridiculous) when facing a border control. However, to characterise what is lumped together under the moniker "cyberspace" in one way or the other seems more arbitrary; while we all know that servers have physical locations, what takes place on our screens does not seem to correspond to that reality. Whatever ontological assumptions one makes has very real effects; just like the arbitrary construct of "territory" affects the life of everyone, ${ }^{71}$ the same may be the case for the construct of "cyberspace".

\section{Final words}

While war may in principle be everywhere, it is an activity which can be limited, and is already subject to regulations. To invoke a war paradigm also for operations outside a war theatre therefore suggests normative consequences. Even when cyber operations do not constitute the kind of belligerency that is regulated by the Hague and Geneva Conventions, it is easy to argue that some of the same principles should apply, like the crucial principles of distinction (between military and civilian) or proportionality (between military gain and "collateral damage"). (This also appears to be US policy; Lin \& Zegart, 2019, p. 12) If civilians should be spared in war, it seems illogical to not spare

Sovereignty, belligerency and the new normal in cyberspace Wrange.docx 
them in operations below the thresholds of armed conflict, like cyber espionage and other cyber operations. If we are in a war (or quasi-war) paradigm, then cyber operations against ISIS are surely legitimate, but not indiscriminate operations against anyone.

However, if there is no need to invoke belligerent (or quasi-belligerent) rights, because a state can use its sovereign rights on foreign territory uninhibited by sovereignty, and if that state - like the United States - also believes that human rights do not apply outside its own territory (United States Observations, 2017, paras 13-15; Fidler, 2013, p. 113; see also Wrange, 2014, p 324-326), then there are no legal reasons to spare other governments, political opponents, dissenters, commercial competitors or anyone else whose whereabouts might be of interest to that state. ${ }^{72}$ The activities of George Smiley and his KGB counterpart Karla ${ }^{73}$ were "not of particular interest to the general public or human rights and civil liberties advocates" (quote from Deeks, 2015, p. 299), but in present "cyberspace", with its "ubiquitous interconnectivity [and] its lack of segregation between the private and public sectors" things are very different. As one commentator noted, "cyberspace feels in many respects a Hobbesian domain" (Watts \& Richard, 2018, p. 840) with the important clarification that the cyber Leviathans have their "their weapons pointing, and their eyes fixed" not only on one another, but on each and all of us.

\section{References:}

Adams, M.J. (2014) Jus Extra Bellum: Reconstructing the Ordinary, Realistic Conditions of Peace. Harvard National Security Journal, 5, 377.

Barlow, J.P. (1996). A Declaration of the Independence of Cyberspace. http://w2.eff.org/Censorship/Internet_censorship_bills/barlow_0296.declaration (last accessed 13 October 2013).

Tsagourias, N. (2015) The legal status of cyberspace. In Research handbook on international law and cyberspace. Edward Elgar Publishing, 13.

Buchan, R. (2015). Cyber espionage and international law. In Research handbook on international law and cyberspace. Edward Elgar Publishing, 168.

Tsagourias, N., \& Buchan, R. (Eds.). (2015). Research Handbook on International Law and Cyberspace. Edward Elgar Publishing.

Buchan, R. (2012) Cyber Attacks: Unlawful Uses of Force or Prohibited Interventions? Journal of Conflict and Security Law, 17, 211, 218-219.

Cassese, A. (2004). International Law. $2^{\text {nd }}$ ed, Oxford University Press

Sovereignty, belligerency and the new normal in cyberspace Wrange.docx 
Chesterman, S. (2006). The Spy Who Came in from the Cold War: Intelligence and International Law. Michigan Journal of International Law, 27, 1071.

Chesterman, S. (2009) Secret Intelligence, The Max-Planck Encyclopedia of Public International Law. on-line version, accessed 7 December, 2012.

Cohen, Julie E. (2007) Cyberspace As/And Space. Columbia Law Review, 107, 210.

Constitution of the International Telecommunication Union, as amended 2010. Retrieved 10 October, 2019 from

http://www.itu.int/en/history/Pages/ConstitutionAndConvention.aspx,

Corfu Channel, see International Court of Justice

Corn, G.P. \& Jensen, E.T. (2018a) The Technicolor Zone of Cyberspace (Part I). Just

Security. Retrieved 10 October, 2019 from

https://www.justsecurity.org/57217/technicolor-zone-cyberspace-part/

Corn, G.P. \& Jensen, E.T. (2018b) The Technicolor Zone of Cyberspace (Part II). Just Security. Retrieved 10 October, 2019 from

https://www.justsecurity.org/57545/technicolor-zone-cyberspace-part-2/

Corn, G.P. \& Taylor, R. (2017). Sovereignty in the Age of Cyber, AJIL Unbound, 111, 207212.

Corn, G.P. (2017). Tallinn Manual 2.0 - Advancing the Conversation. Just Security blog, Retrieved 10 October, 2019 from https://www.justsecurity.org/37812/tallinn-manual-2-0advancing-conversation/.

Deeks, A. (2013). The Geography of Cyber Conflict: Through a Glass Darkly. International Law Studies, 89, 1.

Deeks, A. (2015). An International Legal Framework for Surveillance. Virginia Journal of International Law, 55, 291.

Deibert, R. (2015). The geopolitics of cyberspace after Snowden. Current

History, 114(768), 9.

Dickinson, L. (2018). Not-War Everywhere: A Response to Rosa Brooks's How

Everything Became War and the Military Became Everything. Temple International and Comparative Law Journal, 32.1, 17.

Egan, B. J. (2017). International Law and Stability in Cybershpace. Berkeley J. Int'l L., 35, 169.

Farrell, H. \& Glaser, C.L. (2019). How Effects, Saliencies, and Norms Should Influence U.S. Cyberwar Doctrine. In H. Lin and A. Zegart (Eds), Bytes, Bombs, and Spies: The Strategic Dimensions of Offensive Cyber Operations, Washington DC: Brookings Institution

Sovereignty, belligerency and the new normal in cyberspace Wrange.docx 
Press, 45.

Fidler, D.P. (2011). Was Stuxnet an Act of War? Decoding a Cyberattack. IEEE Security $\mathcal{E}$ Privacy Magazine, 9, 56-59.

Fidler, D.P. (2012). Revelations Concerning Cybersecurity, Recent Developments and Revelations Concerning Cybersecurity and Cyberspace : Implications for International Law. ASIL Insights, 16:22.

Fisher, D.I (1990) Prior Consent to International Direct Satellite Broadcasting. Leiden: Martinus Nijhoff Publishers.

France, Ministère des Armées. (2019). Droit international appliqué aux opérations dans le cyberespace, Retrieved 10 October, 2019 from $<$ https://www.defense.gouv.fr/content/download/565895/9750877/file/Droit+internat+ap pliqu \%C3\%A9+aux+op\%C3\%A9rations+Cyberespace.pdf>

Forcese, C (2011) Spies Without Borders: International Law and Intelligence Collection. Journal of National Security Law and Policy, 179.

Gill, T.D. (2013) Non-Intervention in the Cyber Context. In K. Ziolkowski (Ed.), Peacetime Regime for State Activities in Cyberspace. International Law, International Relations and Diplomacy, Tallinn: NATO CCD COE Publication, 217.

Goldsmith, J (2001) The Internet and the Legitimacy of Remote Cross-Border Searches. Public Law and Legal Theory Working Paper No 16, University of Chicago Legal Forum, Retrieved 10 October, 2019 from

https://chicagounbound.uchicago.edu/cgi/viewcontent.cgi?referer=\&httpsredir=1\&articl $\underline{\mathrm{e}=1316 \& \text { context }=\text { public law and legal theory }}$

Hayden, M. V. (2016). Playing to the Edge: American Intelligence in the Age of Terror, Penguin.

Heinegg, W.H. von. (2012). Legal implications of territorial sovereignty in cyberspace. In C Czosseck, R Ottis, \& K Ziolkowski (Eds.). 4th International Conference on Cyber Conflict, 7-19. Retrieved 10 October, 2019 from

http://ieeexplore.ieee.org/xpls/abs_all.jsp?arnumber=6243962.

Henkin, L. (1995). International Law: Politics and Value. Leiden \& Boston: Nijhoff Inglis, C. (2019). Illuminating a New Domain: The Role and Nature of Military Intelligence, Surveillance, and Reconnaissance in Cyberspace. In H. Lin and A. Zegart (Eds), Bytes, Bombs, and Spies: The Strategic Dimensions of Offensive Cyber Operations, Washington DC: Brookings Institution Press, 19.

International Court of Justice (ICJ). (1949). Corfu Channel (the U.K. v. Albania), I.C.J. Reports, 4, 35.

Sovereignty, belligerency and the new normal in cyberspace Wrange.docx 
Island of Palmas, see Permanent Court of Arbitration

Jennings, R. \& Watts, A., eds. (2008) Oppenheim's International Law. 9th ed.

Jensen, E.T. (2017). The Tallinn Manual 2.0: Highlights and Insights. Georgia International Law Journal, 48, 735.

Kanuck, S. (2010). Sovereign Discourse on Cyber Conflict Under International Law. Texas Law Review, 88, 1571.

Kerschischnig, G. (2012) Cyberthreats and International Law. The Hague: Eleven International Publishing, 131.

Kilovaty, I. (2016). World Wide Web of Exploitations-The Case of Peacetime Cyber Espionage Operations under International Law: Towards a Contextual Approach. The Columbia Science ETechnology Law Review, 18, 42-78.

Kjaergaard Christensen, K. \& Liebetrau, T. (2016). Security Meets Cyberspace: The Politics of Cyber Security. Unpublished paper. Retrieved 10 October, 2019 from https://dpsa.dk/papers/Security\%20Meets\%20Cyberspace\%20\%20The \%20Politics\%20of\%20Cyber\%20Security\%20DRAFT.pdf. Cited with permission from the authors.

Kozik, A.L. (2015). The Concept of Sovereignty as a Foundation for Determining the Legality of the Conduct of States in Cyberspace. Baltic Yearbook of International Law, 14, 93-103.

Lauterpacht, H., ed. (1955). Oppenheim's International Law: Part I. 8th ed.

Lawson, S., \& Gehl, R. W. (2011, May). Convergence security: Cyber-surveillance and the biopolitical production of security. In Workshop on Cyber-Surveillance in Everyday Life: An International Workshop. Retrieved 10 October, 2019 from

https://www.robertwgehl.org/text/convergsec.pdf

Lee, D. (2012). Flame: Massive Cyberattack Discovered, Researchers Say. BBC News, 28 May 2012

Libicki, M.C. (2017). The Coming of Cyber Espionage Norms. In H. Rõigas, R. Jakschis, L. Lindström, T. Minárik (Eds.), 9TH INT'L CONFERENCE ON CYBER CONFLICT, Tallinn: NATO CCD COE Publications, 3.

Libicki, Martin C. (2012). Cyberspace Is Not a Warfighting Domain. I/S: A Journal Of Law And Policy For The Information Society, 8, 321.

Lin, H. \& Zegart, A. (2019). Introduction. In H. Lin and A. Zegart (Eds), Bytes, Bombs, and Spies: The Strategic Dimensions of Offensive Cyber Operations, Washington DC: Brookings Institution Press, 1.

Sovereignty, belligerency and the new normal in cyberspace Wrange.docx 
Lin, H. (2010). Offensive Cyber Operations and the Use of Force. Journal of National Security Law and Policy, 4, 63.

Lotus, see Permanent Court of International Justice

Lubin, A. (2016). Espionage as a Sovereign Right Under International Law and Its Limits,

ILSA Quarterly, 24:3, 22-28,

Lubin, A. (2018). Cyber law and espionage law as communicating vessels. In T. Minárik, R. Jakschis, L. Lindström (Eds.) 10th International Conference on Cyber Conflict CyCon X: Maximising Effects, Tallinn: NATO CCD COE Publications, 203.

Maurer, T. (2014). The Future of War: Cyber is Expanding the Clausewitzian Spectrum of Conflict. Foreign Policy blog. Rertrieved 10 October, 2019 from https://foreignpolicy.com/2014/11/13/the-future-of-war-cyber-is-expanding-theclausewitzian-spectrum-of-conflict/.

Neff, S. (2005). War and the Law of Nations: A General History. Cambridge: Cambridge University

O'Connell, M.E. (2012). 'Cyber Mania'. In O'Connell, M. E., Arimatsu, L., \& Wilmshurst, E. (2012, May). Cyber security and international law. In International Law Meeting Summary, Chatham House, 3. Retrieved 10 October, 2019 from https://www.chathamhouse.org/publications/papers/view/184529/290512summary.pdf O'Connor, J.M. (2017). International Law Framework for Employing Cyber Capabilities in Military Operations, Memorandum from the General Counsel of the Department of Defence. Jan. 19, 2017.

Ohlin, J. D. (2014). Acting as a Sovereign Versus Acting as a Belligerent. In J.D. Ohlin (Ed.), Theoretical Boundaries of Armed Conflict and Human Rights, Cambridge University Press, 118.

Permanent Court of Arbitration, Island of Palmas (Neth. v. U.S.), 2 R.I.A.A 829 (Perm. Ct. Arb. 1928)

Permanent Court of International Justice, Series A.-No. 70 September 7th, 1927, Collection of Judgments, The Case of the S.S. "Lotus".

Rusinova, V. (2019) A Voice of the European Court of Human Rights in Our 'Panoptical' Reality. ESIL Newsletter, March 2019. Retrieved 10 October, 2019 from https://esil-sedi.eu/esil-newsletter-march-2019/.

Schaap, A.J. (2009). Cyber Warfare Operations: Development and Use Under International Law. Air Force Law Review, 64, 121.

Sovereignty, belligerency and the new normal in cyberspace Wrange.docx 
Schmitt, M. (2011). Cyber Operations and the Jud Ad Bellum Revisited. Villanova Law Review, 56, 569

Schmitt, M.N. \& Vihul, L. (2017a). Cyberspace: Lexlata Vel Non? AJIL Unbound, 111, 217.

Schmitt, M.N. \& Vihul, L. (2017b). Respect for Sovereignty in Cyberspace. Texas Law Review, 95, 1639.

Schmitt, M.M. (2013). Cybserspace and International Law: The Penumbral Mist of Uncertainty. Harvard Law Review Forum, 126, 176.

Schmitt, M.N. (2017a) Grey Zones in the International Law of Cyberspace. The Yale Journal of International Law Online, 42, 1.

Schmitt, M.N. (2018) In Defense of Sovereignty in Cyberspace. Just Security blog. Retrieved 10 October, 2019 from https://www.justsecurity.org/55876/defensesovereignty-cyberspace/

Schmitt, M.N. (2019a), France's Major Statement on International Law and Cyber: An Assessment: Use of Force, Sovereignty and More, Just security. Retrieved 20 October, 2019 from https://www.justsecurity.org/66194/frances-major-statement-oninternational-law-and-cyber-an-assessment/.

Schmitt, M.N. (2019b). France Speaks Out on IHL and Cyber Operations: Part I. EJIL: Talk!, Retrieved 20 October, 2019 from https://www.ejiltalk.org/france-speaks-out-onihl-and-cyber-operations-part-i/

Schmitt, M.N. (2019c). France Speaks Out on IHL and Cyber Operations: Part II. EJIL: Talk!, Retrieved 20 October, 2019 from https://www.ejiltalk.org/france-speaks-out-onihl-and-cyber-operations-part-ii/

Schmitt. M.N. (2019d). The Netherlands Releases a Tour de Force on International Law in Cyberspace: Analysis. Just security. Retrieved 20 October, 2019 from https://www.justsecurity.org/66562/the-netherlands-releases-a-tour-de-force-oninternational-law-in-cyberspace-analysis/

Schultz T. (2008). Carving up the Internet: Jurisdiction, Legal Orders, and the Private/Public International Law Interface, European Journal of International Law, 19, 799.

Scott, R. (1999) Territorially Intrusive Intelligence Collection and International Law, The Air Force Law Review, 46, 219.

Segal, A. (2017). The hacked world order: How nations fight, trade, maneuver, and manipulate in the digital age. 2 ed. Hachette UK.

Shackelford, S.J. (2009) From Nuclear War to Net War: Analogizing Cyber Attacks in International Law, Berkeley Journal of International Law, 27, 192,

Sovereignty, belligerency and the new normal in cyberspace Wrange.docx 
Spector P. (2017). In Defense of Sovereignty, in the Wake of Tallinn 2.0, AJIL Unbound, 111, 223.

Sulmasy, G. \& Yoo, J. (2006) Counterintuitive: Intelligence Operations and International Law. Michigan Journal of International Law, 28, 625.

Tallinn Manual 2.0 on the International Law Applicable to Cyber Operations (2017) edited by M. Schmitt \& L. Vihul, Oxford University Press

Tallinn Manual on the International Law Applicable to Cyber Warfare (2013) edited by M. Schmitt \& L. Vihul, Oxford University Press

UNGGE = United Nations General Assembly, 'Group of Governmental Experts on Developments in the Field of Information and Telecommunications in the Context of International Security,' A/68/98, June 24, 2013.

United States Department of Defense (USDOD). (2015). Law of War Manual. Issued by the Office Of General Counsel Department Of Defense, June 2015.

United States (US), Observations of the United States of America On the Human Rights Committee's Draft General Comment No. 36 On Article 6 - Right to Life, October 6, 2017 $<$ https://www.state.gov/wp-content/uploads/2019/05/U.S.-observations-on-DraftGeneral-Comment-No.-36-on-Article-6-Right-to-Life-.pdf > accessed 14 October, 2019.

United States (US), The White House (2016), Report on the Legal and Policy

Frameworks Guiding the United States' Use of Military Force and Related National Security Operations, https://www.justsecurity.org/wpcontent/uploads/2016/12/framework.Report Final.pdf, accessed 2019-10-10.

US Joint Chief of Staffs (USJCS). 2018. Joint Publication 3-12 E Cyberspace Operations, 8 June 2018, <https://www.jcs.mil/Portals/36/Documents/Doctrine/pubs/jp3 12.pdf>, accessed 2019-10-10.

US Supreme Court of the United States, 25 U.S. 1, The Palmyra

von Heinegg, W.H. (2012). Legal implications of territorial sovereignty in cyberspace. In C Czosseck, R Ottis, \& K Ziolkowski (Eds.), 4th International Conference on Cyber Conflict, Tallinn: NATO CCD COE Publications, 7.

Watts, S. \& Richard, T. (2018) Baseline Territorial Sovereignty and Cyberspace. Lewis \& Clark Law Review, 22, 771.

Weber, A.M. (2003). The Council of Europe's Convention on Cybercrime. Berkeley Tech. Law Journal, 18, 425.

Wikipedia, Cyberspace, visited 2019-10-10

Wrange, P. (2014) Intervention in national and private cyberspace and international law.

Sovereignty, belligerency and the new normal in cyberspace Wrange.docx 
In J. Ebbesson, M. Jacobsson, M. Klamberg, D. Langlet and P. Wrange (Eds), International Law and Changing Perceptions of Security: Liber Amicorum Said Mahmoudi, Leiden: Brill/Nijhoff, 307.

Wright, J. (2018). Cyber and International Law in the 21st Century. Address delivered at Chatham House, 23 May 2018. Retrieved 10 October, 2019 from https://www.gov.uk/government/speeches/cyber-and-international-law-in-the-21stcentury

Wright, Q. (1962) Espionage and the Doctrine of Non-Intervention in Internal Affairs. In Roland Stanger (Ed.), Essays on Espionage and International Law, Columbus: Ohio State University Press, 11.

Zhang, Guo and Elin K. Jacob, Reconceptualizing Cyberspace: "Real" Places in Digital SpaceThe International Journal of Science in Society, 3:2, 9.

${ }^{1}$ I would like to thank Linda Bishai, Andreas Behnke, Terry Gill, Gazmej Huskaj, Lars Nicander, the members of the BBL group of the Stockholm Centre for International Law and Justice and participants at a seminar at Higher School of Economics (Moscow) for valuable comments and conversations during the writing process.

${ }^{2}$ I justify this on two grounds: The present book will be published in the US and many of the authors are US-based. Further, US thinking has been very influential in the West, for various reasons, and the US is the most powerful player in the field.

${ }^{3}$ The element of non-permission is important from a legal point of view, but not necessarily so from a military perspective.

${ }^{4}$ The great majority of emails and other communications over the Internet pass through US soil, which of course facilitates SIGINT for the US.

${ }^{5}$ Former NSA chief Michael Hayden writes that "I can think of no other family of weapons so anchored in the espionage services for their development (except perhaps armed drones)." (Hayden, 2016).

${ }^{6}$ The US Cyber force consists of elements from the four armed services and the NSA.

${ }^{7}$ Cf Cohen (2007, p. 255). The discussion on the character of "cyberspace" is multifarious, in different academic disciplines like geography, philosophy and law. See, for instance Zhang and Jacob (2012), who find cyberspace to be a spatial metaphor.

${ }^{8}$ While this part may imply that some of the writers have presented their views for strategic reasons rather than as a result of bona fide analysis, I am not at all suggesting that that is the case. It is one thing for a laywer to find arguments that serve her or his clients or masters, it is another thing to present these arguments in a signed contribution to an academic forum. I find no reason to believe that the views referenced in this chapter are not genuine.

${ }_{9}$ The word is commonly accredited to SciFi writer William Gibson, who used it in 1982, but it appears that it was first used by the Danish visual artist Susanne Ussing in 1968. Wikipedia, Cyberspace, https://en.wikipedia.org/wiki/Cyberspace

${ }^{10}$ To many readers, this practice may seem strange, or even irritating. However, that Verfremdung effect is Sovereignty, belligerency and the new normal in cyberspace Wrange.docx 
intended. (Verfremdung, a literary term coined by Bertold Brecht, is usually translated into alienation or estrangement and sometimes into defamiliarisation.)

${ }^{11}$ For another use, see Ohlin (2014).

${ }^{12}$ It is certainly debatable whether corporate actors, like companies, have human rights. Under the European Convention on Human Rights and Fundamental Freedoms legal persons can file complaints (Article 34), but that does not seem to be the case under the other regional or global conventions. At any rate, the rights of individuals may be affected by actions against corporate actors, and therefore they may at least have indirect rights.

${ }^{13}$ That is, even if A under some circumstances may regulate acts that take effect in B, it cannot enforce that regulation in $\mathrm{B}$.

14 "Armed conflict" is a term of art which by and large has replaced "war" in international law. Since this is not a legal text I will sometimes use "war".

15 These rules are not exhaustive, however; human rights continue to apply (though to a controversial extent), and other laws, like the law on diplomatic relations, generally apply, though with potential exceptions. In particular in US legal discourse, LOAC, the law of armed conflict, is a more common term. It covers IHL as well as some other regulations.

${ }^{16}$ As this section of the Law of War Manual bears out, a state can also exercise both belligerent and sovereign rights against rebels. (USDOD, 2015, p. 1025.) The subjects of a sovereign who use arms against that sovereign can be punished for rebellion under the domestic law of the sovereign. Some theorists think that the two relations - sovereignty and belligerency - exclude one another (an enemy cannot also be a subject), while others believe that the sovereign rights and belligerent rights can apply at the same time in a civil war.

${ }^{17}$ Much of the traffic still passes through the US, but most root servers (which control the Domain Name System) are now outside the US.

${ }_{18}^{18}$ One of the famous expressions of this view is Barlow (2016).

${ }^{19}$ For a very interesting analysis of issues related to jurisdiction, see Schultz (2008).

${ }^{20}$ ICT stands for information and communication technologies. In 2015, the successor GGE elaborated these findings, but did not add much in substance as far as the present subject is concerned.

${ }^{21}$ In 2011, Russia proposed a "Draft Convention on International Information Security", which has not met with general approcal. See comments by Conflict Studies Research Centre at http://www.conflictstudies.org.uk/files/20120426 CSRC IISI Commentary.pdf, accessed 31 March, 2014.

${ }^{22}$ Apart from the statemens by the US and the UK which will be referenced above, France and the Netherlands have also made fairly detailed pronouncements on these matters. See France (2019), Schmitt (2019a, 2019b, 2019c, 2019d). The former US legal adviser Harols Koh made a pioneering presentation already in 2012, although it was considerably more general.

${ }^{23}$ The Grand Chamber of the European Court of Human Rights is expected to issue two important judgments in cases relating to privacy and interception of communication over the Internet. See Rusinova (2019).

${ }^{24}$ Tallinn (2017) is the updated and considerably expanded second edition of Tallinn (2013).

${ }^{25}$ Some writers think so, especially if great financial loss is incurred, See, for instance, Kerschischnig (2012, p. 131 et seq); Schmitt (2011, p. 590); Shackelford (2009, p. 238). See also Waxman (2011, p. 434-435) and Tallinn (2017, p. 343).

${ }^{26}$ The Stuxnet virus, launched in 2010 against Iran -- allegedly by US and/or Israel - is arguably the most sobrestingrify, 
centrifuges in the Iranian nuclear program. See, inter alia, Fidler (2012) and Fidler (2011).

${ }^{27}$ This is somewhat of a simplification, because even jus ad bellum depends on the force being proprtionate. However, that does not need to be sorted out for the present argument.

${ }^{28}$ See note 15.

${ }^{29}$ This is, again, a simplification, but the finer points of any distinction between the two is beyond the scope of this chapter and they are not relevant for the main argument.

${ }^{30}$ Further, since cyber operations almost always are secret, it is less likely that such operations will be used to send the type of coercive signal that is involved in intervention.

For many commentators, intervention is only about coercively affecting the will of another state regarding matter $X$, not about taking matter $X$ into its own hands (see above). So, if state $A$ exerts coercive pressure on state $\mathrm{B}$ to to have citizen $\mathrm{X}$ of $\mathrm{B}$ extradited, this pressurizing might constitute intervention. However, if state A instead takes the matter in its own hands, and kidnaps X on B's territory and brings her into A, this would not amount to intervention under this strict interpretation (although it might, and most likely would, violate other rules.)

${ }^{31}$ In the famous Stuxnet incident, a USB memory stick was inserted into a computer in Iran, which most likely necessitated the presence of an agent on Iranian territory. That is, however, an exception.

32 This has been discussed with regard to law enforcement by, inter alia, Goldsmith (2001).

${ }^{33}$ The adjectives "accessory" or "associated" in this context are not terms of art, and will be used intgerchangeably.

${ }^{34}$ A fairly early and well-known example is the Flame virus, which infected 1000 computers, mostly in Iran (Lee, 2012).

${ }^{35}$ In wartime, espionage is considered to be legal, but a spy who is caught does not have the right to be treated as a prisoner of war and can be prosecuted.

${ }^{36}$ One of the legal views that I will present below, the restricted one, happens to coincide with what I would write in a legal brief or a doctrinal article. I will, of course, nevertheless try to present the other opinions in the best possible light -- usually by generously quoting -- but I will allow myself to occasionally be mildly polemic, though only in the footnotes.

${ }^{37}$ Even states that in wartime might profit from taking the battle to "cyberspace" (as is already the rule) have serious civilian vulnerabilities. North Korea may be an exception. Cf also Deeks (2013, p. 19).

${ }^{38}$ I have borrowed the terms from Watts and Richard (2015).

${ }^{39}$ The distinction between a rule and a principle is a contentious matter. For some lawyers, the distinction is just one of level of abstraction, while for others, rules are binding whereas principles should merely be considered. Corn is obviously of the latter view. By contrast, in the Lotus judgment (which Corn cites, but to support if a different view), the word "principle" is used 77 times, generally - if not exclusively - to refer to something that is binding. (SS.Lotus, 1927, passim.)

${ }^{40}$ The supporters of the view that sovereignty is a binding rule invoke many sources, from court practice to prominent doctrine. Watts (2018) invokes the International Court of Justices first case, Corfu Channel, "Between independent States, respect for territorial sovereignty is an essential foundation of international relations." Spector (2017 p. 221) invokes Cassese 2004, p. 48 \& 51; Lauterpacht 1955, p. 327-28: Jennings \& Watts 2008. p. 432; Henkin, 1995, p. 221.

A number of examples of acts that states view as violations of sovereignty are also invoked, such as nonmilitary overflights and law enforcement investigations on foreign territory (Spector, 2017, p. 222).

${ }^{41}$ In this respect, the Manual essentially builds on the UN International Law Commission's Articles on StateeResigotsibbielligideretedynąodt the new normal in cyberspace Wrange.docx 
42 To simplify a bit: Tu quoque means that state A cannot invoke rule $\mathrm{X}$ against state $\mathrm{B}$ if it has itself violated that rule, for instance by committing espionage itself. Estoppel has a similar effect, meaning that state A cannot rely on rule $\mathrm{X}$ if it has implicitly disavowed that rule. I am grateful to Professor Sundberg for having pointed out this argument. On the relevance of this argument in relation to the U2 incident, see Wright (1962, p. 19). Cf also Shackelford (2009, p. 27; Watts \& Richard 2018, p. 817).

${ }^{43}$ This also happens to be my own position, presented in Wrange (2014).

${ }^{44}$ Perhaps the principle of non-intervention goes even further and excludes all forms of investigations by law enforcement authorities on foreign soil. However, that is not how it is spelt out in the Friendly Relations Declaration and in practice of the International Court of Justce, which both have a more limited conception. See text around n 30.

Under the Council of Europe's Budapest Convention on Cybercrime - which has been ratified also by some non-European countries, including the US - a number of acts, commonly conducted as a part of law enforcement or cyber espionage (see below), are criminalized. This includes illegal access and illegal interception, and the Convention contains no exceptions for measures taken by foreign public agencies. In fact, the preparatory works of the Convention clearly spell out that the Convention does not allow remote extraterritorial search. See Weber (2003, p. 433). For further analysis and sources, see Wrange (2014, p. 315 and passim).

${ }^{45}$ DdoS= distributed denial of services. It is essentially an operation, involving multiple computers, which aims to impede the operation of a server or network by overwhelming it with a flood of Internet traffic which the server or network does not have the capacity to handle.

${ }^{46}$ Governments value secrecy highly, in commercial and in government matters. In fact, much data loses its value if it is no longer secret.

${ }^{47}$ Another argument for this conclusion is that espionage is allowed since there is no prohibition under international law. This argument addresses the opinion that espionage is prohibited since it violates domestic law (see below). This view is not very common, and since this article focuses on the associated act of hacking -- rather than the mere extraction of information -- it need not be discussed here.

${ }^{48}$ I do agree with this objection. However, this objection may not hold in the future, since the US in particular is in the process of trying to establish such an opinio juris, in so far as it amounts to “information necessary for national security decisions" (Watts, 2018, p. 818; Libicki, 2017).

${ }^{49}$ According to one commentator, this carveout would cover information related to national security, not least military capabilities (Deeks, 2015, p. 305). Farrell and Glaser (2019, p. 67) explain that the US "holds that there is a basic distinction between purely commercial cyber exploitation (securing commerical secrets that are then shared with favores domestic businesses - which it considers illegitimate) and regular cyber exploitation (gathering information relevant to cyber security - which the United States considers legitimate)."

${ }^{50}$ The concept is not a very well established one, but it has featured, for instance in the Palmyra case in the US Supreme Court (25 U.S. 1) of 1827.

${ }^{51}$ As mentioned above, there is no doubt that cyber espionage as well as offensive cyber operations are allowed within the theatre of hostilities.

${ }^{52}$ Corn's analysis of the options of countermeasures and necessity is more restrictive than what international law actually allows, in my reading. I agree in general with Schmitt's analysis. See Schmitt (2018).

${ }^{53}$ Very recently, France and the Netherlands have issued statements about their views on cyber operations. Both belong to what Watts and I call the sovereigntist camp. See sources cited in note 22.

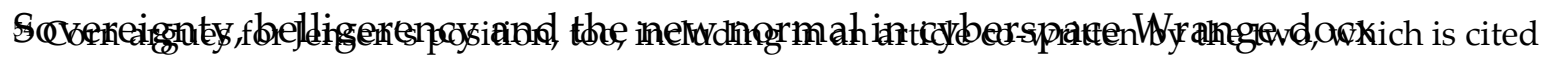


below.

55 I must confess to having been flabbergasted the first time I came across it.

56 In fact, "the rule of prohibited intervention can serve as a powerful tool for enforcing acceptable state behavior in cyberspace" (Corn \& Jensen, 2018b).

57 O'Connor (2018) is cited from Watts \& Richard (2018, p. 827). The memo was first distributed widely and then "quickly designated 'internal distribution only'. (Schmitt, 2017, p 5). Interestingly enough, $\mathrm{O}^{\prime}$ Connor also appears to have been one of originally three authors of the piece cited below as Corn \& Taylor, because that is how Schmitt cites that piece in (2017), apparently fter having read a draft thereof. $\mathrm{O}^{\prime}$ Connor evidently retracted from authorship before the publication of the finished pieces.

58 Watts \& Richard (2018, p. 828), citing from O'Connor (2017, p. 2-3).

59 Robert S. Taylor is a Former Principal Deputy General Counsel, DoD.

60 Taylor \& Corn praise the "UK's resounding rejection of the existence of a primary norm of territorial sovereignty, which would make internationally wrongful a nonconsensual interference in the computer networks of another state." "[H]is speech is an extremely important statement by one of the major cyber powers in the international community" (Corn \& Taylor, 2018.

61 This is how the Obama administration explains this doctrine: "In particular, there will be cases in which there is a reasonable and objective basis for concluding that the territorial State is unable or unwilling to confront effectively a non-State actor in its territory so that it is necessary to act in self-defense against the non-State actor in that State's territory without its consent." (US White House, 2016, p.10). Deeks (2013) analyses this concept as relevant to cyber conflict.

62 Another burdon is that the state that claims belligerent rights have to explain that it does so in selfdefense and not as an aggressor.

${ }^{63}$ Recall that Corn did not find these grounds sufficient.

${ }^{64}$ In the US, the "merger" between the NSA and the military side has created a "blending of offensive and defensive capabilities with intelligence" which is "central to how the United States thinks of cyber" (Segal, 2017, p. 143).

65 The next sentence in the judgment - but not in Corns quotation -- is: "Now the first and foremost restriction imposed by international law upon a State is that --- failing the existence of a permissive rule to the contrary -- it may not exercise its power in any form in the territory of another State", which was cited above. (PCIJ, 1927, p 18.)

66 The analogy is not perfect. The territorial sea may extend up to 12 nautical miles beyond the so-called base-line, which runs along the coastline. In this part of the sea, foreign ships may traverse, and the coastal state's jurisdiction is very limited. However, in distinction to the diluted "cyberspace", foreign states can exercise jurisdiction only regarding their own ships. See Articles 17-26, the United Nations Convention on the Law of the Sea.

67 It is notable that Jensen allow acts that "do not impinge on the inherently governmental functions of another state". This seems to accept economic espionage, and thus privilege "inherently governmental functions" over other activities in a society. (Not to mention that it also assumes a certain view of what the proper function of a government is.) On the other hand, it appears to be a US view that espionage on corporations is illegitimate whereas espionage on other states is not. As mentioned, the distinction between private and public targets is interesting as such, but beyond the scope of this chapter.

68 This idea has been criticized from a strategic point of view by Libicki (2012).

69 The US Law of War manual does not accept the "exceptionalism" idea that "cyberspace" is something sompletely different.over which statę cannot exercise sovereignty (See Watts, 2015, pp- 59-60; cf also 
USDOD, 2015, p. 997).

${ }^{70}$ It needs to be pointed out, though, that while this applies applies to the Internet in general, much Internet traffic goes through specially designated "tunnels", which actually makes it possible to know how the information is routed.

${ }^{71}$ This is not to say that I necessarily disapprove of all legal and political arrangements made based on that construct.

72 The US claims to use its alleged rights responsibly. Nevertheless, the law that the US Cyber Command seems to be projecting can be invoked by any state actor - China, Russia, North Korea, Iran, etc.

${ }^{73}$ Protagonists of a number of John Le Carré spy novels. 